\title{
Valentina Živković
}

\section{Visions of the Blessed Osanna of Kotor (Cattaro)}

UDK: 7.046(497.16 Kotor)"15"

235.3 Ozana Kotorka, blažena
Valentina Živković

Institute for Balkan Studies, Serbian Academy of Sciences and Arts, Serbia

Valentina.Zivkovic@bi.sanu.ac.rs

The paper looks at the visions of the Blessed Osanna of Kotor (1493-1565), a Dominican tertiary who came to adopt an austere form of asceticism - reclusion. Recognisable in Osanna's visions is a strong influence of the artistic images and religious themes popular in contemporary Kotor, a coastal town at the far end of the Gulf of Kotor (Bocca di Cattaro), in modern day Montenegro. The recognition of links between texts, mental images and visual art images makes it possible to embark upon the study of the religious, social and historical context of the Blessed Osanna's emergence and role in Kotor in the first half of the sixteenth century.

Keywords: the Blessed Osanna, Kotor, visions, reclusa incarcerata, Dominican tertiary, living saint, Imitatio Christi, religious painting

The Blessed Osanna was a Dominican tertiary who, even during the course of her lifetime in the first half of the $16^{\text {th }}$ century, was extraordinarily revered in Kotor, a coastal town at the far end of the Gulf of Kotor (Bocca di Cattaro), in modern day Montenegro (fig. 1). Her veneration developed into a sacred local cult, which along with the patron of the town, St Tryphon, enjoyed immense esteem from the people of Kotor. Her spiritual biography, Vita della reverenda serva di Dio la madre suor Ossanna da Cattaro, dell'ordine di San Domenico was written by the Dominican monk Serafino Razzi after his residence in Kotor in 1589, and was published in Florence in 1592. Other works were written about Osanna's life and miracles. A contemporary of the Blessed Osanna, Bazilije Gradić, a Benedictine monk from Dubrovnik, wrote about her life in his work Libarce od djevstva dated 1567, and the work was translated into Italian and published in Rome at a later date. In the first half of the $17^{\text {th }}$ century, Vicko Bolica (who also used the surname Kokoljić, which is the other family name of this branch of the noble Bolica family) penned a canto in the national language, which was merely an adaptation of one part of Razzi's Vita. The Dubrovnik-based Dominican monk Serafin Crijević (1686-1759) translated Osanna's Vita written by a Kotor author, her contemporary, from its poor Italian, as Crijević himself said, into Latin.'

The Blessed Osanna was born as Katarina Kosić in 1493 in the village of Relezi in Montenegro, into an Orthodox Christian family, and, as Razzi points out: setta dei Greci detti Rasciani, "and today we consider them as schismatics". It is an interesting fact that Osanna's family produced more than a few Orthodox priests. Katarina died as Osanna, a Dominican reclusa incarcerata in Kotor in 1565, at the time when Kotor was part of the Venetian Republic (1420 - 1797). With the fall of Zeta (Montenegro) under the Ottoman Empire, a great number of people from the continental area moved to the coast. Poverty and the insecurity of war prompted families to send their daughters to work in Kotor, as was also the destiny of Katarina Kosić, who, after her father's demise, came to work as a servant girl in the household of a prominent Kotor patrician family, the Buchias. Kotor, to which the Montenegrin shepherdess arrived with the desire to see God, was a town with an extensive tradition - historical, urban, cultural and ecclesiastical, similar to the Dalmatian townships on the Eastern Adriatic coast (fig. 2). The members 
of the patrician Buchia family, to whose home Osanna came to serve, were prominent in secular and church politics, in endowments, economics and diplomacy - from the age when the town was a part of the Serbian medieval Nemanjić state. Written sources, such as the Statute of Kotor and judicial/notarial records, provide information about the municipal institutions and a well-organised urban life, public as well as private. Kotor was a Catholic bishopric under the jurisdiction of the Archbishop of Bari, and within the town itself, bounded by bastions there were, by the end of the $15^{\text {th }}$ century, some thirty churches. However, until the last decades of the $17^{\text {th }}$ century, there was not one Orthodox church in the town itself and the Orthodox Christian population mostly lived in the villages nearby the town of Kotor - this was the social and religious framework which the cult of the Blessed Osanna of Kotor rose from. The rudiments of this cult proffer a profusion of material for the researching of various topics.

On this occasion, my intention was to separate from the hagiography of the Blessed Osanna some visions (which she had had from childhood) and then to reflect on their advent, type and particularly their depiction within the context of Kotor society, history, religious and church art in the first half of the $16^{\text {th }}$ century. Prior to this it is necessary to reflect on one important, and, when it comes to the area of Kotor, inadequately explored issue, this being Osanna's choice of reclusion as a model of asceticism. Especially accentuated in her Vita is the fact that her decision aroused much astonishment amongst the local people as they had not known that an eremitic life could be practiced within an urban environment until then. The concept of a "desert in the midst of an urban ambiance" is the key to understanding Osanna's distinct ascetic accomplishment. At the time when Osanna arrived in Kotor, a tradition of reclusion, or hermitage, had already been established. From the late medieval period onwards, both laymen and women were given the opportunity to lead semi-monastic lives, and even to engage in various forms of asceticism (piçocara, reclusa and heremita). The type of asceticism pursued by the reclusae became particularly favoured after the Observant Franciscan and Dominican reforms in the mid- $15^{\text {th }}$ century. The reclusae incarceratae, whose ascetic lives and mystical prophetic visions earned them veneration even during their lifetimes, represented a special cogency within their towns, which would become especially visible during wars and epidemics. ${ }^{2}$ An especially potent model for strengthening and popularizing the Sisters of the Third Order in Kotor was the cult of the tertiary of the Dominican Order, St Catherine of Siena, who in the mid- $15^{\text {th }}$ century was extremely well revered in Kotor. A testimonial of the formed cult of this patron saint in Kotor is the existence of her relic, as well as a fresco of a $15^{\text {th }}$ century performance in a church today dedicated to St Anne (fig. 3). ${ }^{3}$

The Vita of the Blessed Osanna of Kotor contains several themes typical of late medieval piety: the theme of prayer offered in religious ecstasy coupled with visions of Christ and the saints; the topic of penitence coupled with compassio and meditation on the Passion; the theme of prophetic visions; and the theme of purgatory, with an emphasis on the pro remedio animae prayers as being effective in reining in suffering. Like her role models, the Dominican tertiaries - Santa Caterina da Siena and Osanna da Mantova, the Blessed Osanna turned to secular politics and decried the discord and arguments of the Christian rulers at the time of the escalation of the Ottoman conquest. ${ }^{4}$

The apex of Osanna's asceticism and bonding with God were her visions. They would ensue after great selfmortification, relentless rapturous praying with many spilt tears, and with the rising of the spirit beyond the senses. They were described in ecphrasis, testifying to the powerful impact of the artistic images and the role of physical visions in stimulating meditation and forming mystical visions. Though the ultimate aim was religious contemplation devoid of images, it was common for mental images to follow after prayers, and inspiration was sought in religious art. The theologian, whose writings could also be found among the incunables of the Kotor bishopric, Jean Gerson, in developing a classical Augustine division of visions in three categories: corporal, spiritual, and imaginary (as equipoised by Thomas Aquinas), stressed the relevance of painting in stimulating imaginary visions. ${ }^{5}$ Visions as religious events gained their full significance in the late medieval ascetic practices of the mystics, especially women. The exaltations of women mystics were followed by visions, which were basically under the strong influence of images. This is how they are described in hagiographs, which were offered to readers as the perfect lives of ascetics. ${ }^{6}$ 
While there were certainly male mystics and ascetics, especially St Francis of Assisi, who contributed to this line of development, the fact is that religious women, unlike men, were unable to speak with religious authority in the church unless they were visionaries and committed to a life of deliberate pain. Thus, visions were an opportunity for the saints to actively participate in religious life, to use words in conveying comfort and learning to laymen. Among the gifts, which the female mystics had, there is mention of the power to heal, to predict, but also the gift of weeping as a form of self-expression. Mysticism united the strength of the mind, the power of words and the clarity of visions.?

The significance of physical viewing the external world for the forming of Osanna's first visions was especially stressed by her hagiographer, Serafino Razzi. Depicting the condition of Osanna's spirit, which preceded the visions, Serafino wrote how she observed nature and the heavenly heights, exalted herself in meditating about God, and surrendered herself to contemplation by gazing at the sun and the glow of the twinkling stars in the starry sky. While she led the sheep to the meadows, she would separate herself from the others and be "weeping and sighing much from the bottom of her heart" she would pray to God, seeking from Him "to see you but only once, as I would then see all good". Following Osanna's desire to see God (a physical corporeal view) the first vision ensued: she saw a very beautiful child in a meadow by a river. She ran to embrace it, but suddenly the child arose and refused to be touched or to be seen any longer. With joy, she ran off to tell her mother the story, saying that "Woe unto me, how quickly this joyful vision has left me." Her mother became frightened that "she, in such a way terrified and beside herself, would speak of these visions". After that, she had an apparition of the divine Birth, followed by a vision of the Passion of Christ. Unlike the clement setting of the first vision of the Birth, the vision of the Passion occurred upon a high and lonely hill, with the noon light shining brightly - she saw, in the air, the Saviour nailed to the cross. She was "wounded in the heart by the dagger of compassion" by this vision, and from then on her desire to go to Kotor became even stronger, in order to be apprised of divine secrets.

The Blessed Osanna had conventional visions and their formulaic character is strategically positioned to create a desired hagiographic effect. Visual meditations on Christ's birth and the Passion came before her conversion - for these were considered appropriate subjects for beginners - the first step in becoming a visionary and the beginning of her ascetic practice and self-mortification. The baroque poet from Kotor, Vicko Bolica, wrote in verses penned a century after the death of the Blessed Osanna about her and also stressed the significance of visions. According to this poet, Osanna, prior to coming to Kotor, yearned for the following: "Oh, to be blessed to see you, dear God, if only with but one eye". Due to her mother telling her that the "image" of the Creator of the world was located in Kotor, Osanna sought the following: "Lead me to Kotor, to feast my eyes without end!" so her mother sent her to Kotor to be a servant girl in the house of Aleksandar Buchia.

Osanna's visions, according to the themes and descriptions, are the closest link with the key topics in the religious practices of Kotor of the Late Medieval and Early Modern periods. The preserved religious artworks attest to this, stressing the correlation between the visual and the visionary. A prominent place in Osanna's Vita is given to the vision that came prior to her final decision to dedicate her life to God in austere asceticism. After she received Holy Communion in one of Kotor's churches, while attending Mass, she had a vision of the Crucifix, that is, of Christ spilling blood profusely, she saw the Crucifix and herself by the right side of the cross. The vision made her faint and she remained "like dead" for several hours. In her Vita, it is emphasised that during this vision Osanna, "burning with divine love", received many spiritual rewards. Very soon after this vision, she attended the Good Friday sermon about the Passion and became resolute in becoming an anchoress and meditate on the suffering of Christ until the end of her life.

It should be mentioned in this context that the apse of the Cathedral of St Tryphon holds a fresco of the Passion and Crucifixion scenes from the first half of the $14^{\text {th }}$ century (figs. 4, 5). There is an especially interesting iconographic interpretation in the apse of the Church of Santa Maria Collegiata (fig. 6). Like the croce dipinta in the fresco technique, the cycles of the Passion and Resurrection Appearances are arranged in three registers 


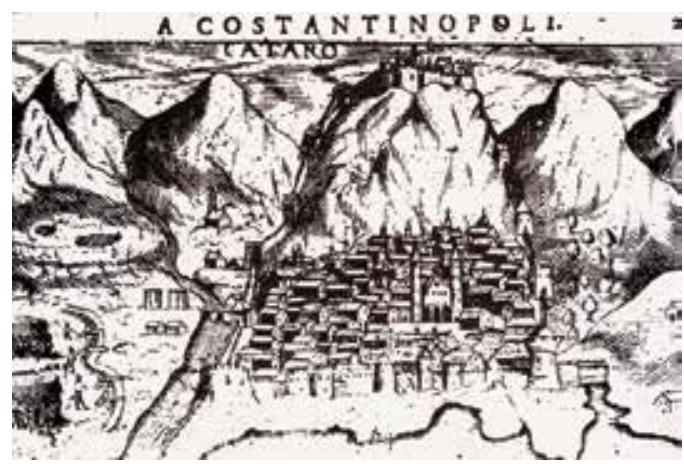

1. Cattaro, Giuseppe Rosaccio, engraving, $16^{\text {th }}$ century

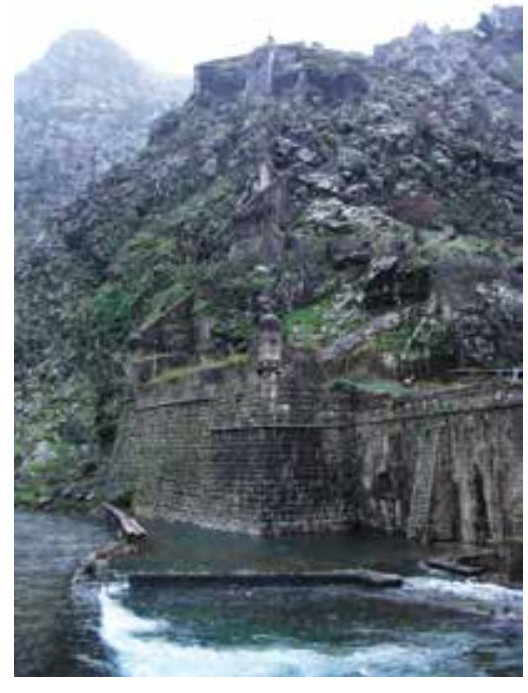

2. Kotor, northern city walls

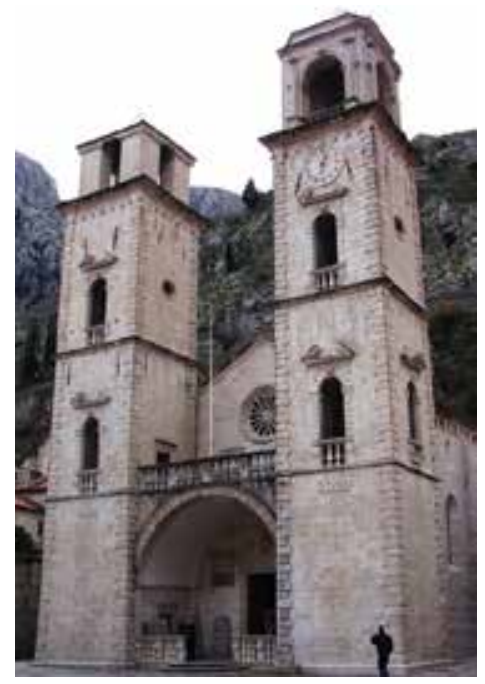

4. St Tryphon's Cathedral

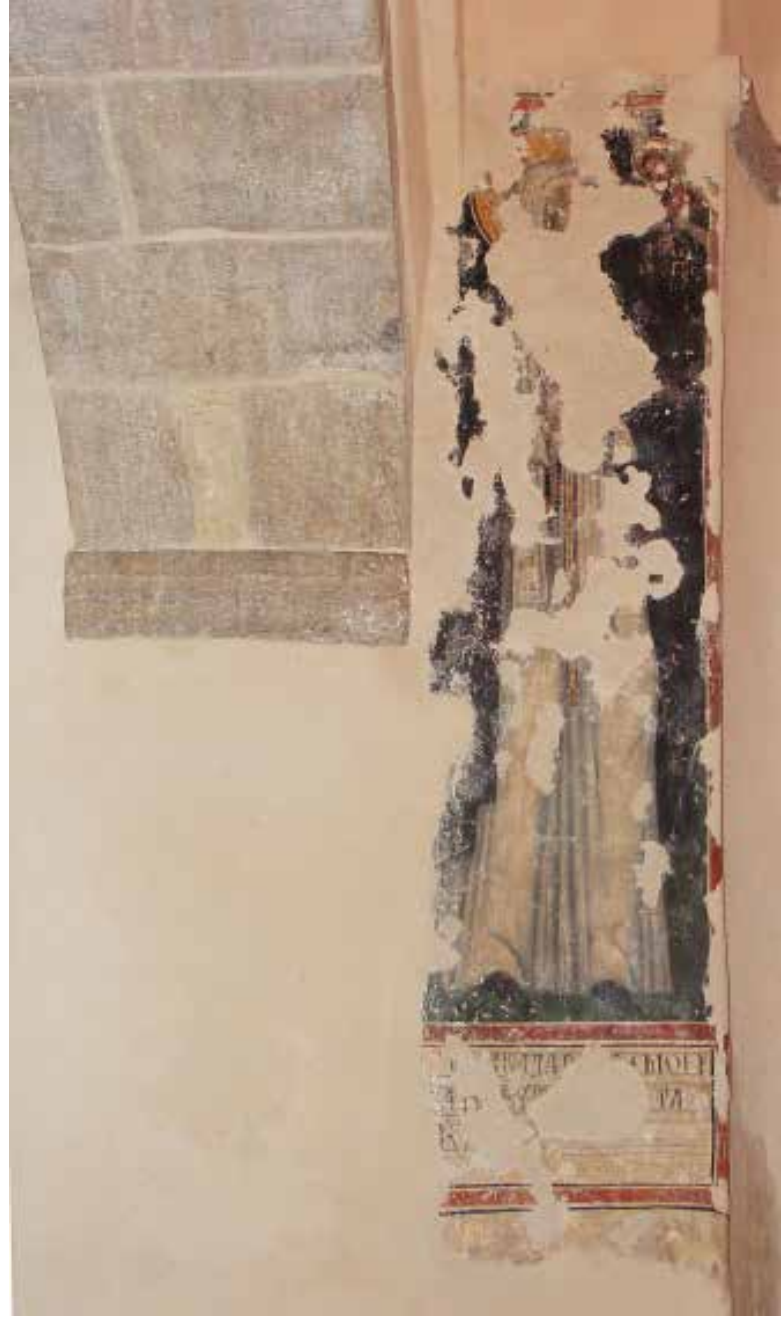

3. St Catherine of Siena, St Anne's church, $15^{\text {th }}$ century

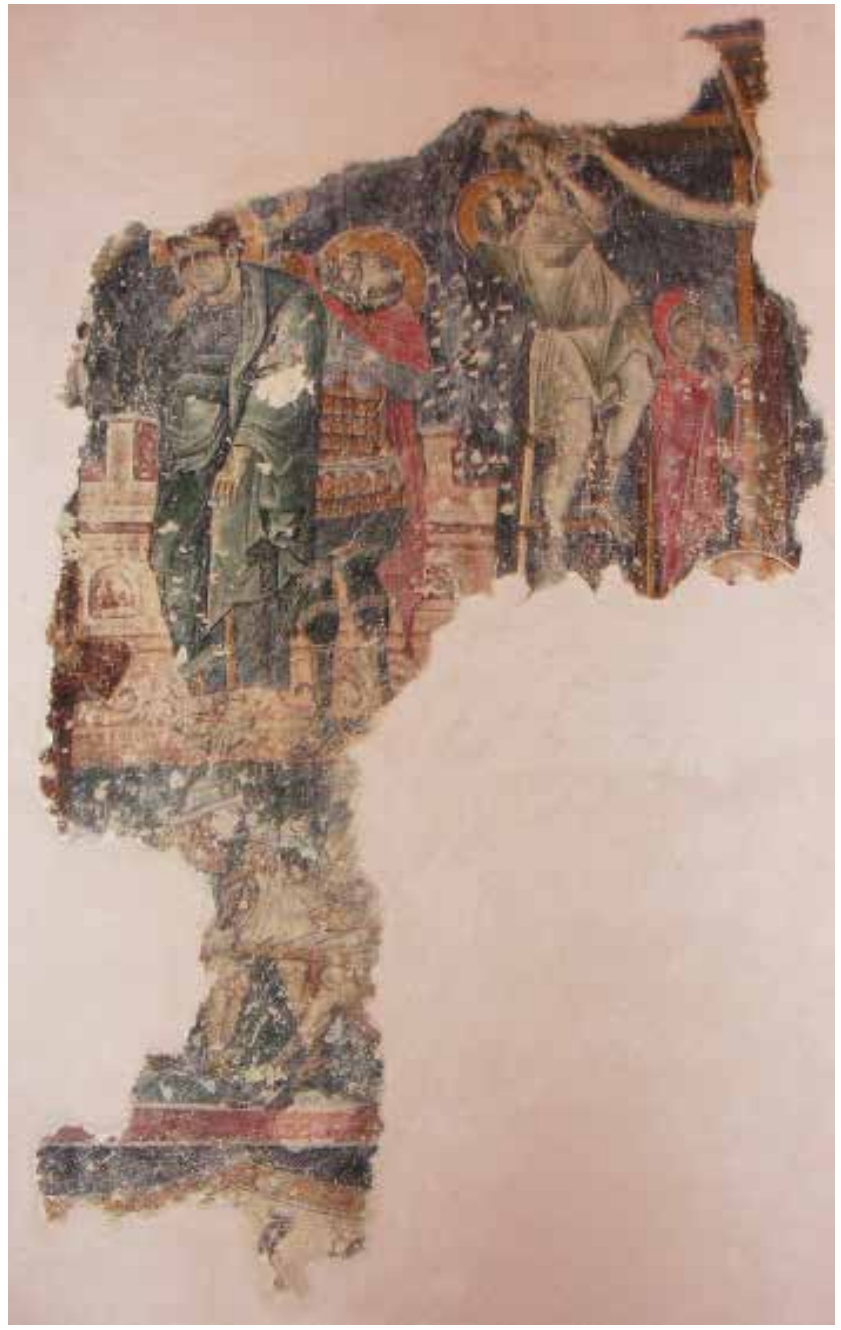

5. Crucifixion and Descent from the Cross, St Tryphon's Cathedral, $14^{\text {th }}$ century 


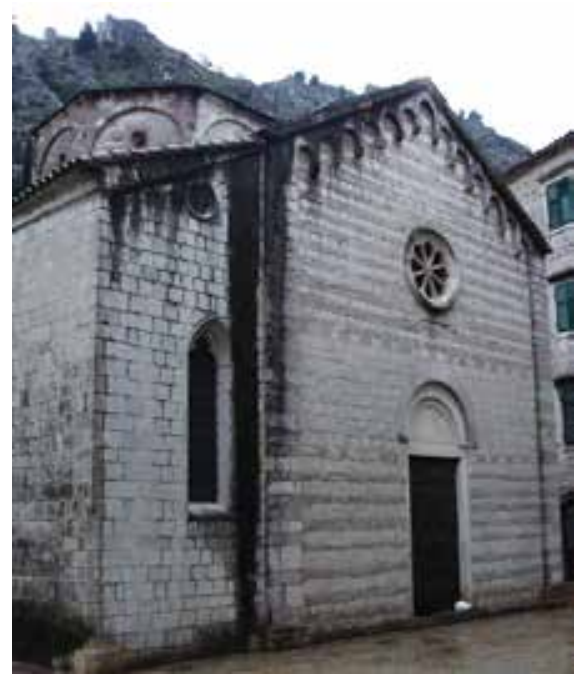

6. St Mary's Collegiate church

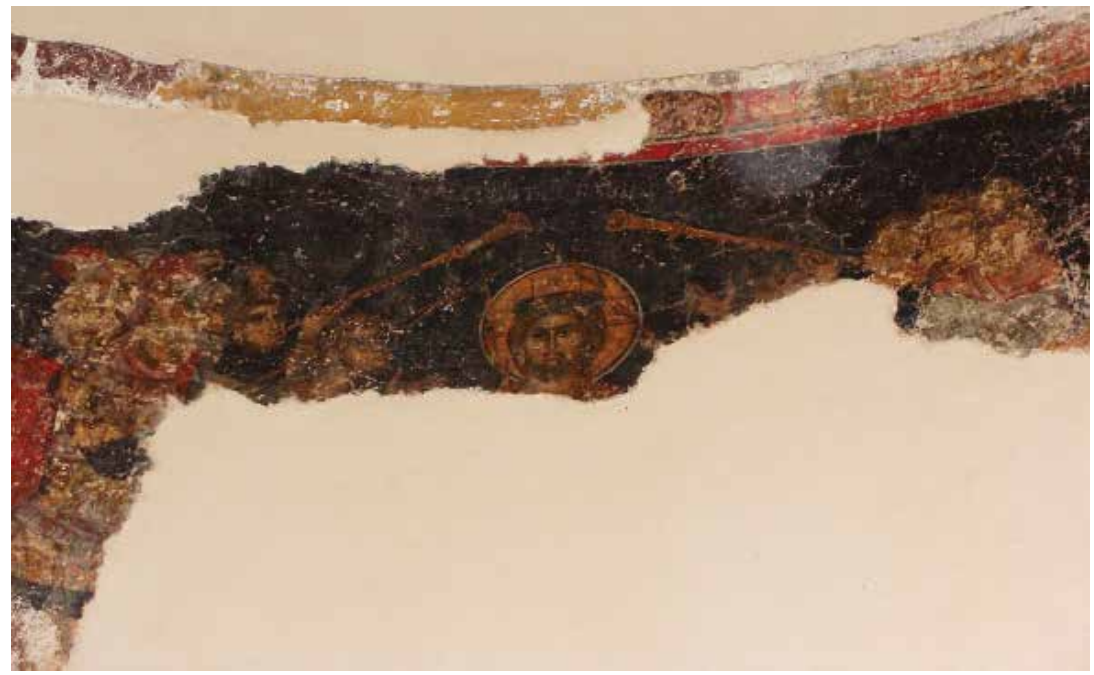

7. Mocking of Christ, St Mary's Collegiate church, $14^{\text {th }}$ century

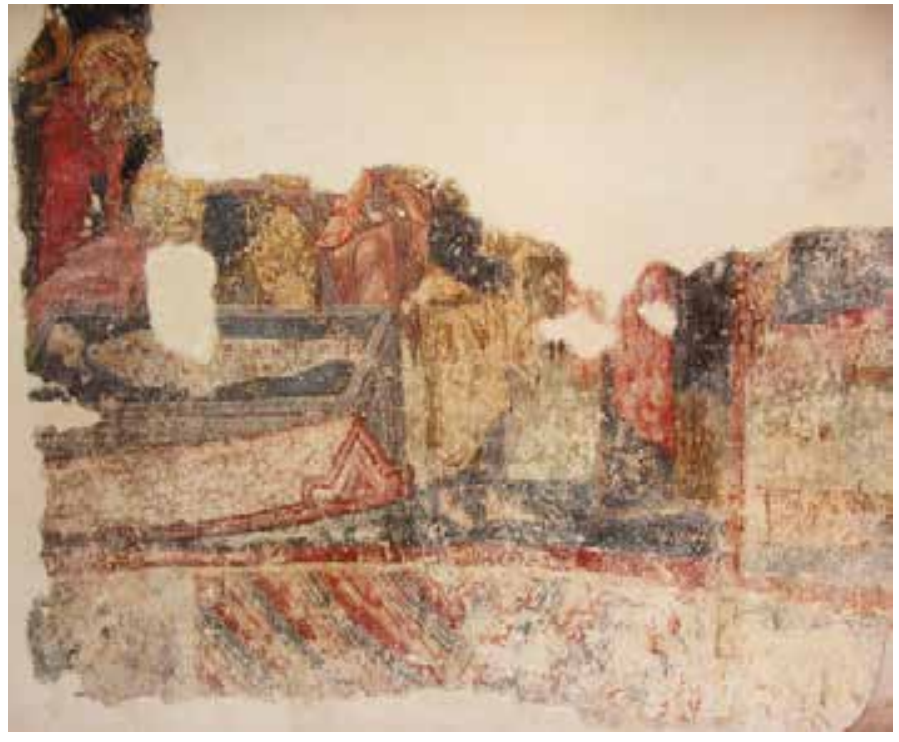

8. Apostles Discovering the Empty Tomb, St Mary's Collegiate church, $14^{\text {th }}$ century

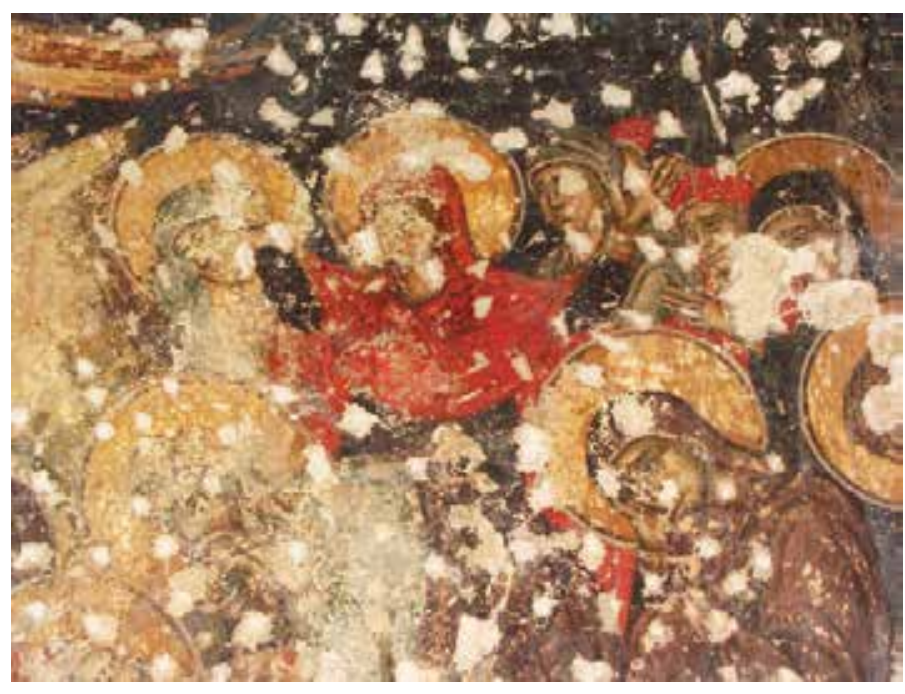

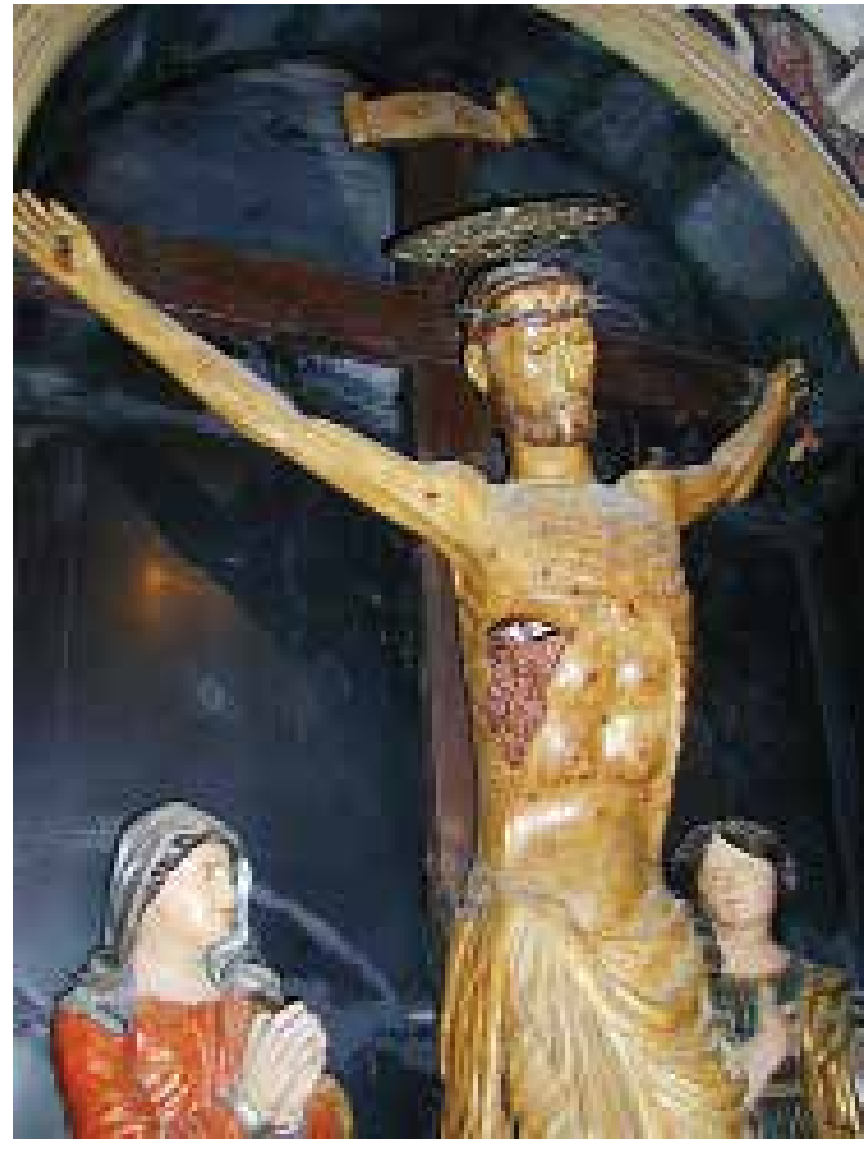

10. Wooden crucifix, $14^{\text {th }}$ century, St Mary's Collegiate church 
round the central Crucifixion scene, which is larger and constitutes the formal and conceptual backbone of the pictorial programme (figs. 7-9). The frescoes were painted at the beginning of the $14^{\text {th }}$ century, and the choice of scenes in the lower registers have a distinctive symbolic meaning and form a whole with the Eucharistic rites of depositio, elevatio and visitatio performed in the apse. It can only be presumed that Osanna received Holy Communion, after which followed a vision of the crucified Christ in the very Church of Santa Maria Collegiata. What is certain is that these frescoes constituted a visual framework for Osanna's religious fervour and imaginary visions. In the $15^{\text {th }}$ century in the Church of Santa Maria Collegiata, a new altar was placed, which likely held the preserved Gothic "miraculous" wooden crucifix (fig. 10). The naturalistically rendered wounds on the body of Christ carried Eucharistic symbolism and were to inspire compassion and meditation on Christ's sufferings. The Quinquepartitum vulnus cult was represented in Kotor and can be encountered in church art, in the religious practices of the people of Kotor, as well as in Osanna's Vita (fig. 11). The bed upon which Osanna slept in her cell was a ladder of five steps in commemoration of the five wounds of Christ of which she "spoke with the sweetest pleasure", according to Serafino Razzi.

The horrendous wounds of Christ and the blood pouring out of them can also be found in a double-sided icon showing Imago pietatis on one side and the Virgin and the Child on the other, which Đurađ Bazilj painted in 1468, most likely for the Flagellant Fraternity (fig. 12). Osanna's second vision of the Crucifixion should be mentioned in this context - while running a high fever, after taking leave from her senses, she saw Jesus upon the cross bathed in blood, and it seemed as if he were asking her whether the anguish he was undergoing for her sake was not of a greater consequence than her illness? Furthermore, Osanna's biographer pointed out that after this vision she recovered her health and expressed to others the message that Jesus had undergone his suffering for the sake of our health. Hence, the visions gave the legitimacy to women mystics to teach the faithful in religious lessons. There will be more on the privileges which Osanna enjoyed in Kotor society later in this text.

The vision of the crucified Christ and herself beside the cross finally confirmed Osanna's desire to meditate on the suffering of Christ and follow the model of Imitatio Christi by way of the most rigorous asceticism, in the spiritual as well as spatial sense, and to the end of her earthly life. Obtaining a licence from the bishop of Kotor, Osanna was walled up in a small cell. Her first cell was in the corner of St Bartholomew's Church, between the city walls in the north-western part of town. This was a tiny square room where she spent seven years. After this, she was transferred to an even smaller cell, in the corner of St Paul's Church, as seven years prior to that, when she was picking herbs on the hill above the church, the Holy Spirit had revealed to her that this was the place whereupon she was to end her journey (fig. 13). St Paul's Church was the first Dominican monastery in Kotor. ${ }^{8}$ She donned a Dominican habit and changed her name to Osanna, conducting rigorous fasting and undergoing tortuous thirst. Every week she took Holy Communion. Underneath her robe, around her naked body she wore a tight iron girdle with a coarse sackcloth. During the night, she would pray for a long periods, flagellating herself with whips with small pieces of metal at the tips. She, like St Jerome, also struck herself in the chest with heavy rocks, spilling many a tear. ${ }^{9}$ She was also tantalized by the devil that appeared to her as the spitting image of her confessor Vincent Buchia, then as some birds, and subsequently as the Madonna with Child. Osanna considered herself an inadequate servant of Christ, unworthy of any forgiveness. If someone would brand her a saint, she would scream that she was but a pitiable sinner, unable to withstand this commendation. She wished the people of Kotor would banish her from the town with invectives and stones, as this would be the imitatio of the suffering of Christ. These are the elements which follow this first stage of purgation - self-punishment, degradation and public humiliation.

This stage of Osanna's Vita was followed by visions and miracles which were resolutely coupled to the environment of Kotor and should be looked at in that context. These were visions as responses to the realistic historical events and natural disasters faced by the people of Kotor. The local character of these prophetic visions was granted by the sacred patrons of the town whom Osanna referred to in her prayers. These visions and miracles matched the increasing reputation which Osanna was gaining, that of a living saint. The people of Kotor, the 
nobility, commoners, theologians, as well as foreigners and pilgrims, visited her for advice and prayer, "as to a celestial oracle", as her biographer maintained. Osanna acquired the respect of her contemporaries during her lifetime, which also carried with it the possibility to instruct her fellow citizens in church doctrines, especially about the theme of purgatory. When asked by the people of Kotor, the theologians as well as the laymen, if there were devils in purgatory, Osanna said that she knew a person who was there in spirit (speaking about her own visions in the third person) ${ }^{10}$ and that she had seen a large and deep well in total darkness, though occasionally lit by a fleeting light. In that well were those whom the living could help with prayers, charitable deeds, and especially with sacred sacrifices at the altar. Three enlightening stories about her contemporaries from Kotor (one young Dominican male and two prominent members of the Buchia and Bisanti families) followed after this. Their souls were saved from the prolonged suffering of purgatory by Osanna's prayers, but also by their families' donations to the church. The text even mentions a clause from the Kotor statute - the soul of Jeronimo Bizanti was saved from purgatory stipulating that his wife is, in his name, to donate a fourth of her dowry to the poor.

Osanna, as a living saint, had the gift of prophesy and the powers of working miracles, accompanied by visions. This involved miracles which were linked with various problems, illnesses and natural disasters which were being faced by the people of Kotor. When the neighbouring town of Dubrovnik was struck by a horrible epidemic of the plague in 1533, Osanna's prayers for it not to spread to Kotor were answered. She also prayed that the great flood which struck Kotor would stop. Furthermore, she prophesied a great earthquake - she most likely had a vision. During Osanna's lifetime, two devastating earthquakes struck Kotor - the first one in 1537 and an even stronger one in 1563. On one occasion, while she was praying at daybreak, she had an apparition of beautiful virgins entering St Paul's Church holding lit firebrands. Following this vision, Osanna gathered the sorores tertii habitus, who were hitherto living in their homes, and founded the monastery for the tertiaries next to St Paul's Church. The Master of the Order of the Dominicans from Rome, with decrees made in 1547 and 1548, allowed Osanna and another three Sisters of the Third Order to wear a blessed white scapular (scapularem album) until their demise, much like the Sisters of the Second Order. This was an extremely venerated privilege, which the Master bestowed only for great contributions."

Several visions which we shall discuss have a pronounced local character and a visual framework can be seen in the artistic images popular in contemporary Kotor. What all these visions, which centred on local difficulties, had in common was Osanna's appeal for helping St Vincent Ferrer, her patron. Thus these sections from Osanna's Vita represent a singular written source about the acknowledgment and development of the Dominican predicants cult in Kotor. Namely, in the first half of the $16^{\text {th }}$ century, St Vincent was celebrated as one of the sacred patrons of the town. The cult of another preacher had a similar development - the Franciscan de observantia, San Bernardino da Siena. In written sources and religious art, their cults were frequently linked to St Tryphon, the patron of Kotor. At the end of the $15^{\text {th }}$ century, the Church or Chapel of St Vincent Ferrer was erected next to the Dominican monastery of St Nicholas, outside the fortifications of the town. It was likely that the Dubrovnikbased painter Božidar Vlatković created a painted polyptych at the end of the $15^{\text {th }}$ century, which contained the preserved wooden statue of St Vincent, exhibited during preaching, with a mouth half-open (fig. 14).12 According to a contract, which in 1495 Božidar Vlatković, the father of the renowned Dubrovnik painter Nikola Božidarević, made with the prior of the Kotor-based Dominican monk Peter de Draconibus, the altarpiece for the church of the Dominican monastery in Kotor, St Nicholas', the image of St Vincent should be placed in the middle, which would be surrounded by scenes of the miracles he enacted (unam pallam pro altari cum imagine seu figura sancti Vincentii, ordinis predicatorum, et cum aliis miraculis). ${ }^{13}$ It was instructed that the Kotor altarpiece should be made according to the altarpiece on the altar of the Dominican church in Dubrovnik, which also positioned the figure of St Vincent in the middle. This involved the altarpiece which was painted by Stjepan Zornelić and Marin Lovrov in 1487. It should be pointed out that the contract stressed that the Kotor altarpiece should be illa qualitate, forma et perfectione palle predicte altaris sancti Vincentii hic Ragusii. ${ }^{14}$ 
Osanna's choice of St Vincent as a special patron had everything to do with the personality of her confessor, who bore the name of the saint. This was Father Vincent Buchia, the Dominican priest who became renowned due to his sermons and theological writings. It should be reiterated that Father Vincent Buchia came from the prominent family for which Osanna served, whose forefather, Nikola Buchia, built the first Dominican monastery in Kotor outside the city walls in 1344. Razzi's depiction of Osanna's prayers and visions bear witness to the addition of local elements to the cult of St Vincent, which hitherto pertained only to the town's patron, St Tryphon (fig. 15). Two saints, Tryphon and Vincent Ferrer answered Osanna's prayers during the assault of the Turkish admiral, Hayreddin Barbarossa and his fleet upon the town. Also, at the time when Kotor was struck by una certa mortalità infermità which took many lives, Osanna prayed for the well-being of the town and in her religious ecstasy she had an apparition of her benefactor, St Vincent Ferrer, who told her to wipe away her tears as her prayers would be answered by God.

The third vision of Osanna's apparition of St Vincent should be especially delved into due to its unequivocal depiction of a religious topic, at that time a much-loved one in religious art. Namely, a rancorous altercation had broken out between the nobility and the commoners in Kotor, which escalated to such a degree that it seemed it would not be resolved without blood being spilt. Osanna resorted to prayer and when she rose in religious ecstasy she saw the image of the Madonna, surrounded by St Tryphon on her right and St Vincent, "also one of the special patrons of the town" on her left side. An undeniable impact of the then very popular art theme Madonna della Misericordia was confirmed by the words from Vita that Osanna had seen St Tryphon holding onto the Madonna's mantle with his left hand, and with his right pacifying the armed nobility gathered on St Tryphon's Square, while St Vincent with his right hand spreads the Madonna's mantle over the citizens of Kotor in order to protect them. With his left hand St Vincent was protecting the commoners on the square from the sea, wishing to make peace between them and the nobility. The Fraternity of St Tryphon has its altar in the Cathedral of St Tryphon in Kotor. Thus, according to the decree of the Fraternity from 1413 we find out that masses were held ante gloriosissima Virginis imaginem. Considering that the members lay their solemn oath to Beatissimae Mariae de Misericordia and St Tryphon, it can be presumed that the image of Madonna della Misericordia was presented at the altar. It is important to point out that the mentioned Fraternity decree had proclaimed that St Tryphon would pour forth on the people of Kotor the suam misericordiam. The link with Osanna's vision is clear from the standpoint of the artistic motif and theological teachings. However, the description of the vision in Osanna's Vita also opens the question of how church and secular policies were reflected on the development of sacred town patron cults. The Dominican preacher St Vincent Ferrer was given the task of protecting the commoners, as well as the entire population of Kotor and to appease the feuding sides. Osanna's biographer rendered to the old town patron, St Tryphon, the role of pacifying only the nobility of Kotor. On one hand, in this can be seen Osanna's personal link with St Vincent, as well as the overall idea presented by the mendicant orders - the spreading of the faith and religious teachings amongst the laymen of all social strata and classes. Also, in analysing this motif of the vision one should bear in mind the possible influence of Venetian secular and church politics. Namely, from the very beginning of its rule in Kotor in 1420, Venice had attempted to progressively constrain the town's identity, from re-evaluating the legal stipulations of the Kotor statute, to imposing the duty of honouring St Mark in the same way as the local patron, St Tryphon. Also, in the areas under its control, Venice above all strengthened the cults of specific saints, among which were the Dominican St Vincent Ferrer, Osanna's sacred patron, and St Catherine of Siena, Osanna's role model..$^{15}$

The constructing of the local cult of the Blessed Osanna, a living saint and a Dominican tertiary who originated from an Orthodox Christian family, is a reflection of the singular confessional and historical circumstances in Kotor and its setting. The compelling advent of the Kotor recluse made her an especially potent model for bearing religious teachings. ${ }^{16}$ Thus, an apperception of the links between texts, mental images and visual art images makes it possible to embark upon the study of the social and religious contexts of the Blessed Osanna's rise and task in the first half of the $16^{\text {th }}$ century in Kotor. 


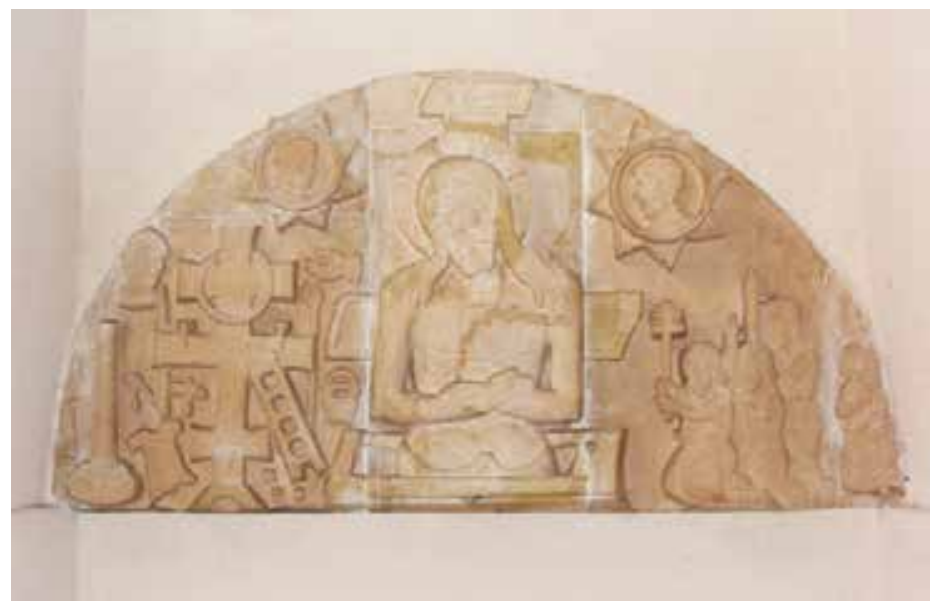

11. Imago Pietatis, relief, $15^{\text {th }}$ century, St Tryphon's Cathedral

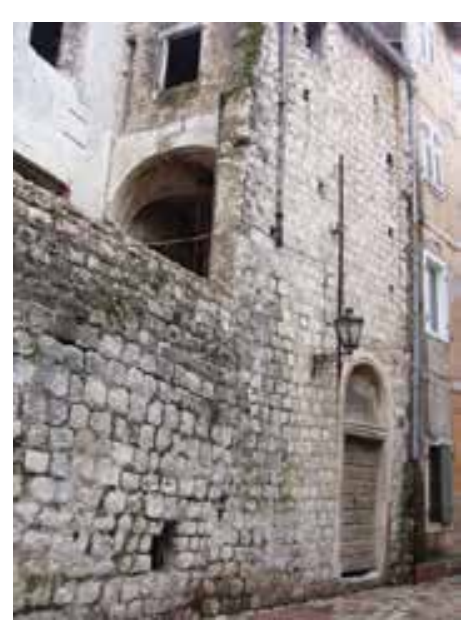

13. St Paul's church

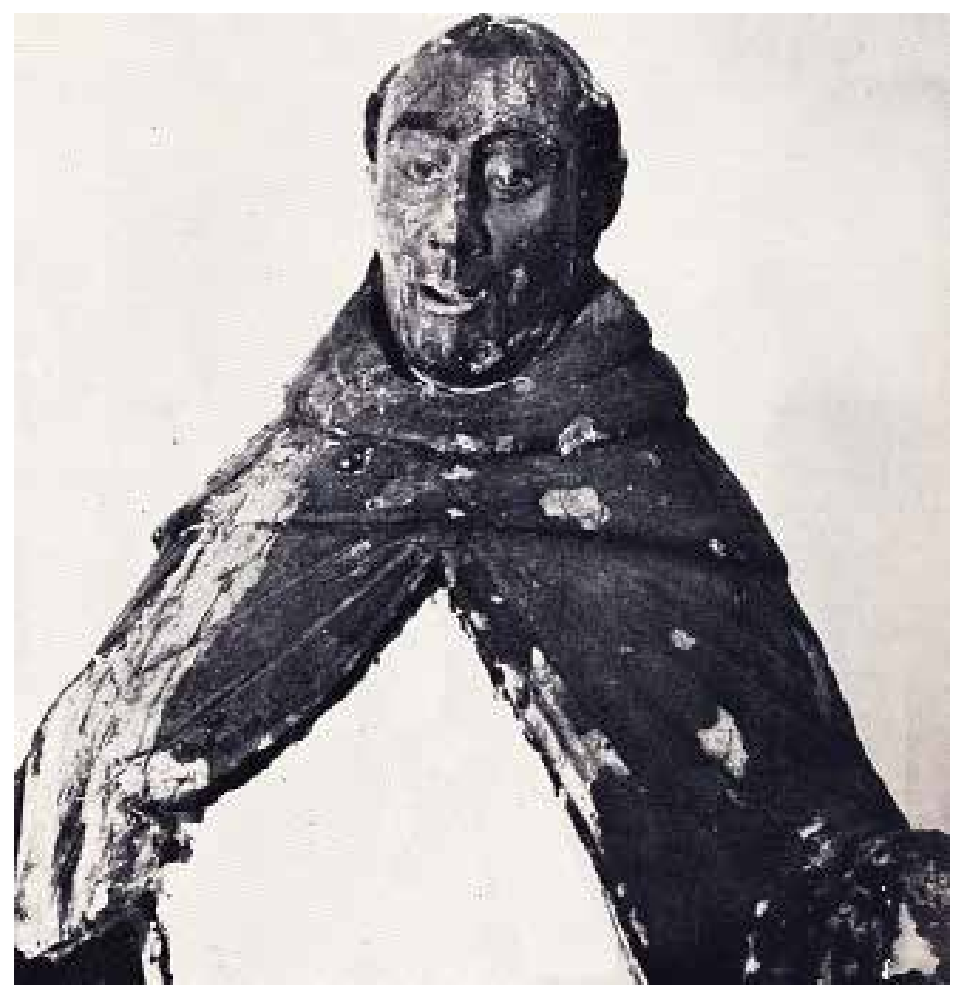

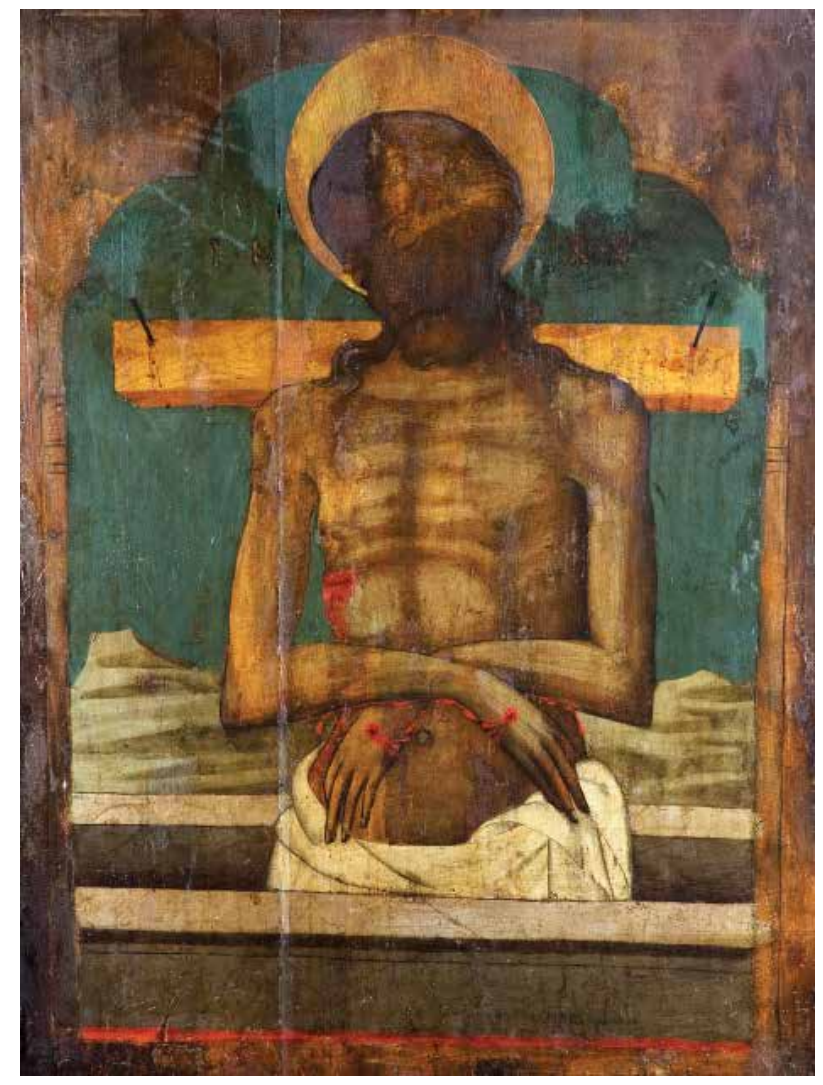

12. : Imago Pietatis, double-sided icon, $15^{\text {th }}$ century, St Tryphon's Cathedral

14. St Vincent Ferrer, wooden statue, $15^{\text {th }}$ century

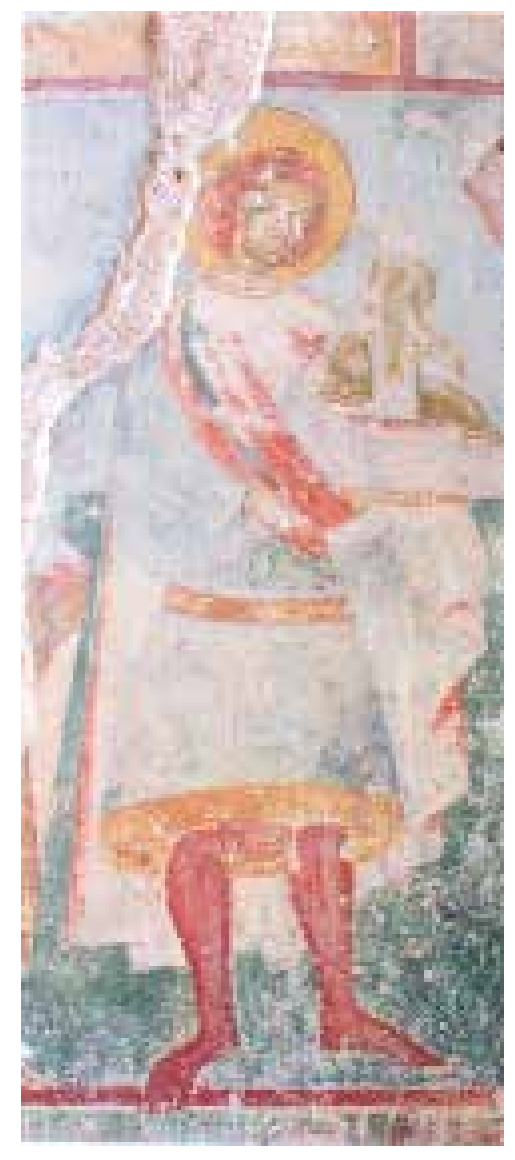


1 On the authors of the Vita of the Kotor recluse see: N. LUKOVIĆ, Blažena Ozana Kotorka, Kotor, 1965, pp. 103-118. Serafino Razzi wrote the Vita of the Blessed Osanna, based on a number of existing manuscripts. He received the manuscript in Latin from Dubrovnik nobleman and Benedictine monk Don Euzebio Kaboga, which was based on the vita in the vernacular language. During his stay in Kotor, Serafino Razzi came upon another manuscript in Italian, Vita della Beata Osanna da Cattaro, written by Ivan Bolica, a contemporary of Osanna. Razzi scripted Osanna's Vita according to the testimonials of witnesses, among which especially prominent were the testimonials of Osanna's fellow Sister Dominica, who was supposedly 110 years old at the time. From the year 1624, Timotej Cizila included Serafino's Vita in his Bove d'oro, which (according to the transcript from 1887) was published in the following: Аналисти. Хроничари Биографи. Књижевност Црне Горе од ХІІ до ХІХ вијека, М. МИЛОШЕВИЋ (ed.), Cetinje, 1996, pp. 102-129. The poem by Vicko Bolica was published in: Пјесници барока и просвећености. Књижевност Црне Горе од ХІІ до ХІХ вијека, М. Пантић (ed.), Cetinje, 1996, pp. 119-127. On the model fuga mundi, the epithets incarcerata, cellana, reclusa, murata and the phenomenon of the city reclusorium see: M. SENSI, Anchorites in the Italian tradition, in: Anchoritic Traditions of Medieval Europe, L. HERBERT MCAVOY (ed.), Woodbridge, 2010, pp. 62-90. On the typology of female reclusion in Italy, cfr. A. BENVENUTI PAPI, ,In castro poenitentiae": santità e società femminile nell'Italia medievale, in: Italia Sacra Studi e Documenti di Storia Ecclesiastica 45, Roma, 1990; A. GIANNI, Iconografia delle sante cellane: Verdiana, Giovanna, Umiltà, in: Santità ed eremitismo nella Toscana medievale, Atti delle giornate di studio (11-12 giugno 1999), A. GIANNI (ed.), Siena, 2000, pp. 67-90; M. SENSI, "Mulieres in ecclesia". Storie di monache e bizzoche, Spoleto, 2010. On the development of the cult of St Catherine of Siena, see: A. VAUCHEZ, Sainthood in the Later Middle Ages, Cambridge, 1997, pp. 87-88, 209-211, 385 et passim. In the Dominican church of St Nicholas in Kotor, the relics of the garments of St Catherine of Siena were enshrined, see: S. KRASIĆ, Nekadašnji dominikanski samostan Sv. Nikole u Kotoru (1266 - 1807), in: Prilozi povijesti umjetnosti u Dalmaciji, 28, Split, 1989, p. 138. On the fresco from Kotor of St Catherine of Siena (represented with a halo and marked as holy) in the church of St Anne, cfr. R. VUJIČIĆ, O novootkrivenim freskama u crkvi Sv. Ane u Kotoru, in: Boka 15, Herceg-Novi, 1983, pp. 423-435; В. ЖИВКОВИЋ, Фреске из ХV века у которској иркви Свете Ане. Иконографска анализа, in: 3ограф 28, Beograd, 2001, pp. 133-138. The visions and prayers which the Blessed Osanna had also relate to the military, diplomatic and political events of the time. This can primarily be seen in the tales of the assault on the town by the Turkish admiral of the Ottoman fleet and the infamous pirate (previously the ruler of Algiers and Tunisia) Hayreddin Barbarossa. On the Dominican Sisters of the Third Order (especially Osanna from Mantua), cfr. M. LEHMIJOKI-GARDNER-D. ETHAN BORNSTEIN, Dominican Penitent Women, New Jersey, 2005; T. HERZIG, Savonarola's Women: Visions and Reform in Renaissance Italy, University of Chicago Press, 2008, pp. 111-126, et passim. New insights into the circumstances linked to the penning of the rules for the Dominican soror de penitentia were noted down by: M. LEHMIJOKI-GARDNER, Writing Religious Rules as an Interactive Process: Dominican Penitent Women and the Making of Their Regula, in: Speculum, A Journal of Medieval Studies, vol. 79, no. 3 (July, 2004), pp. 660-687.

Two studies which review the significance of the art performances in the forming of mental visions of the mystics in the late Middle Ages should be emphasized: S. RINGBOM, Devotional Images and Imaginative Devotions. Notes on the Place of Art in Late Medieval Private Piety, in: Gazette des Beaux-Arts LXXIII (March, 1969), pp. 159-170; J. HAMBURGER, The Visual and the Visionary: The Image in Late Medieval Monastic Devotions, in: Viator, Medieval and Renaissance Studies, vol. 20, 1989, pp. 161-182. Jean Gerson was sternly against various late medieval superstitious abuses of images, but he accepted that painting had a role in stimulating imaginative devotions. The aim of the presentation was to direct thoughts ab his visibilibus mente transire ad invisibilia, a corporalibus ad spiritualia (Opera omnia, II, 71 M, Strasbourg, 1514). On the incunables in the Kotor bishopry see: M. MILOŠEVIĆ, Inkunabule i postinkunabule biblioteke Kotorske biskupije, in: Skriptoriji i manastirske biblioteke u Crnoj Gori, Cetinje, 1989, pp. 133-170. BER (ed.), Harvard UP, 1994, pp. 387-390; B. NEWMAN, What Did It Mean to Say "I Saw"? The Clash between Theory and Practice in Medieval Visionary Culture, in: Speculum. A Journal of Medieval Studies, Vol. 80, No. 1 (January, 2005), pp. 1-43. The increase of visionary experiences of Christ can be noticed from the $12^{\text {th }}$ century, especially under the influence of the learning of Bernard of Clairvaux who, along with Biblical scholarship, stressed the relevance of personal experience. The balance between these two concepts is the foundation of late medieval mysticism. On this: R. NEU WATKINS, Two Women Visionaries and Death: Catherine of Siena and Julian of Norwich, in: Numen, International Review for 
the History of Religion, vol. 30, Fasc. 2, Brill Publishers, Leiden, 1983, pp. 174-198; B. MCGUINN, The Changing Shape of Late Medieval Mysticism, in: Church History, Studies in Christianity and Culture, vol. 65, no. 2, Cambridge UP, 1996, pp. 197-219. Elizabeth Petroff classified the common classic division of visionary experience into seven degrees: Purgative, Psychic, Doctrinal, Devotional, Participatory, Unitive and Ordering - each dominated by a specific content and attitude, see: E. PETROFF, Medieval Women Visionaries: Seven Stages to Power, in: Frontiers, A Journal of Women Studies, vol. 3, no. 1, University of Nebraska Press, 1978, pp. 34-45. ment of the Kotor nobleman Nycola Buchia from 1344, the original Dominican church, the endowment of Paulus Bari, was at first abandoned and after that it was rented out together with the land, up to 1540, when it was given over to the Sisters of the Third Order, see: S. KRASIĆ, op. cit., pp. 131-132, n. 10 (according to Roman documents: Archivum Generale Ordinis Predicatorum XIV, liber HHH, fol. 231, 232r, 232v). On the Church of St Paul, its significance in medieval Kotor and the preserved painted decorations, see: Т. Копривица, Црква Светог Павла у Котору, in: Историјски записи 2/1, Podgorica, 2001, pp. 77-99.

9 On the corporal suffering in late medieval religious life cfr. C. BYNUM, Fragmentation and Redemption, New York, 1992. It was common for women to talk or write about their visions in the third person, as Osanna did, according to Serafino Razzi. On the influence which the confessors had on female mystics and their inspiring to express the latter's religious experiences in a literary manner see: D. RÉGNIER-BOHLER, Literary and Mystical Voices, in: A History of Women in the West. Silences of the Middle Ages, pp. 446-448, 467-468.

11 This written source, the first one to mention Osanna, is extremely important also due to the terminology which was used: the sisters of the Third Order are called sorores tertii habitus, while the nuns of the Second Order are called moniales claustrales. Involved are the Regest. IV-29, f. 155. of the Master of the Dominican Order, Fra Francesco Romea da Castiglione, who was the first to publish the Innocenzo Taurisano, Beata Osanna da Cattaro, Roma 1929, 129-131. The transcript was made by N. LUKOVIĆ, op. cit., pp. 51-53.

12 According to the chronicle of the Franciscan Vincent Marija Babic from 1716 (whose transcript is located in the HAZU - Croatian Academy of Sciences and Arts - archives in Zagreb), the statue was made in 1490 in Dubrovnik, by Ivan de Polo, a citizen of Kotor, who paid 100 perper for the statue. After the church of St Nicholas was given over to the Orthodox authorities, the statue of St Vincent was taken to the Church of St Vincent in Skaljari, see: N. LUKOVIĆ, op. cit., pp. 39, 143; M. MILOŠEVIĆ, Ciborij XIV vijeka i ostala plastika, in: 800 godina katedrale Sv. Tripuna u Kotoru (1166-1966), Kotor, 1966, pp. 49-50; К. ПРИЈАТЕЉ, Которски кип св. Винка, in: Зборник за ликовне уметности Матице српске 3, Novi Sad, 1967, pp. 197-204; В. J. Ђурић, Умјетност, in: Историја Црне Горе 2/2, Титоград 1970, pp. 518-519. On the forming of the cult of the Dominican preacher St Vincent, cfr. L.A. SMOLLER, Miracle, Memory, and Meaning in the Canonization of Vincent Ferrer, 1453-1454, in: Speculum, A Journal of Medieval Studies, vol. 73, no. 2 (April, 1998), pp. 429-454; Idem, From Authentic Miracles to a Rhetoric of Authenticity: Examples from the Canonization and Cult of St. Vincent Ferrer, in: Church History, Studies in Christianity and Culture, vol. 80, no. 42, Cambridge UP, 2011, pp. $773-797$.

13 Ј. ТАДИћ, Грађа о сликарској школи у Дубровнику XIII-XVI в, књ. I, Beograd, 1952, pp. 332-333. On the painting opus of Božidar Vlatković, see: В.J. ЂУРИЋ, Дубровачка сликарска школа, Beograd, 1963, pp. 116-124, et passim.

This involves an altarpiece which was painted by Stjepan Zornelić and Marin Lovrov in 1487. The appearance of this altarpiece also testifies to the saved contract which the painters had made with the prior of the Dominican monastery in Dubrovnik. It was said that the altarpiece should have five saintly figures, among which was the one of St Vincent in the middle. Beside him, the following were to be painted: St Thomas, St Peter the Martyr, St Catherine and St Ursula, and all of were to be clad in pano d'oro, see: Ј. ТАДИЋ, ор. cit., р. 303.

15 In promoting the Dominican Observant movement and the Dominican Third Order in Venice, the Dominican friar Tommaso Caffarini di Antonio da Siena was especially prominent. On this, see: G. FREULER, Andrea di Bartolo, Fra Tommaso d'Antonio Caffarini, and Sienese Dominicans in Venice, in: The Art Bulletin, vol. 69, no. 4 (December, 1987), pp. 570-586.

The significance which the living saints had in forming and spreading of religious lessons was in their ascetic practice based on Imitatio Christi. The dynamic and two-way relationship which was developed between society and the living saints is a very interesting issue for research and analysis. The social significance of the living saints in the early $16^{\text {th }}$ century in Italian towns was analyzed by: G. ZARRI, Living Saints: A Typology of Female Sanctity in the Early Sixteenth Century, in: Women and Religion in Medieval and Renaissance Italy, D. BORNSTEIN-R RUSCONI (eds.), The University of Chicago Press, 1996, pp. 219-304. 


\section{Valentina Živković}

\section{Vizije Blažene Ozane iz Kotora}

Tema rada vizije su blažene Ozane iz Kotora, promatrane u religijskom, umjetničkom, povijesnom i društvenom kontekstu kasnosrednjovjekovnog i ranonovovjekovnog Kotora, koji se u to doba nalazio u sastavu Venecijanske Republike (1420.-1797.). Ozaninu hagiografiju, Vita della reverenda serva di Dio la madre suor Ossanna da Cattaro, dell'ordine di San Domenico, napisao je dominikanac Serafino Raci, nakon svog boravka u Kotoru 1589. godine. Blažena Ozana (1493.-1565.) bila je dominikanska trećoretkinja, koja je prihvatila strogi oblik asketizma (rekluziju), koji je u Kotoru već imao ustanovljenu tradiciju. U Ozaninoj hagiografiji ističe se nekoliko važnih kasnosrednjovjekovnih religijskih motiva: molitve u zanosu praćene vizijama Krista i svetaca, pokajanje praćeno compassiom i meditacijom o Muci, ideja čistilišta s naglaskom na učinkovitost molitvi pro remedio animae. Vizije koje je imala tijekom svoga isposničkog života u rekluziji oslikavaju opće religijske teme, kao i nedaće lokalnog karaktera s kojima su se Kotorani u to doba suočavali. Njezino izdizanje iznad osjetila, u duhu, bilo je praćeno mentalnim slikama, koje se u hagiografiji opisuju gotovo u ekfrazama, svjedočeći o snazi utjecaja likovnih religijskih predodžbi i tema koje su u to doba bile omiljene u Kotoru. Uspostavljanjem veze između pisane riječi, odnosno mentalnih slika i vizualne umjetnosti, stvara se temelj za promatranje društvenoga i religijskoga konteksta pojave i uloge koju je blažena Ozana imala u Kotoru u prvoj polovici 16. stoljeća.

Primljeno/Received: 23.10.2012.

Izvorni znanstveni rad 
